\title{
Synthesis of Juglone (5-Hydroxy-1,4-Naphthoquinone) in a Falling Film Microreactor
}

\author{
Oksana Shvydkiv ${ }^{1}$, Carolin Limburg ${ }^{2}$, Kieran Nolan' ${ }^{1}$ and Michael Oelgemöller ${ }^{2 *}$ \\ ${ }^{1}$ School of Chemical Sciences, Dublin City University, Dublin 9, Ireland \\ ${ }^{2}$ School of Pharmacy and Molecular Sciences, James Cook University, Townsville, QLD 4811, Australia
}

\begin{abstract}
Photooxygenation of 1,5-dihydroxynaphthalene to Juglone was studied in a falling film microreactor. Moderate conversion rates of up to $31 \%$ were achieved after just $160 \mathrm{~s}$ of exposure to visible light. In contrast, batch reactions gave much lower conversions of up to $14 \%$ after a prolonged time period of $10 \mathrm{~min}$. The difference in performance is explained by the superior light penetration in the microfilm and the large gas-liquid contact area.
\end{abstract}

Keywords: photooxygenation, falling film microreactor, microflow, photochemistry, juglone

\section{Introduction}

Microflow photochemistry has recently emerged as a new synthesis concept, and numerous examples of selective photochemical transformations have been described [1]. The main advantage of microreactors is the narrow reaction channel that allows for complete penetration of light even at high concentrations of the chromophoric reagent (as expressed in the BeerLambert law) [2]. The flow mode additionally removes the photoproduct from the irradiation zone, thus minimizing secondary photoreactions and decompositions. Most reactions so far have been performed in homogeneous solution phase [3]; however, examples of heterogeneous gas-liquid reactions have also been described [4]. Among these, dye-sensitized photooxygenations are especially interesting since they give oxygenated products under mild and green conditions [5]. These transformations also allow for the application of natural sunlight [6]. Owing to its importance as a natural product and key intermediate in organic synthesis $[7,8]$, the photooxygenation to 5-hydroxy-1,4-naphthoquinone (juglone, 2) from the commercially available 1,5-dihydroxynaphthalene (1) has been intensively studied over the last few years (Scheme 1) [9]. We have consequently investigated this important transformation under microflow conditions and have compared the results with those achieved using a conventional Schlenk flask setup. Rose bengal was chosen as a sensitizer because of its industrial importance and easy availability [5]. Air was used as oxygen source to avoid potentially hazardous exhaust fumes from the falling film reactor. In addition, previous studies have shown that air gives similar results to pure oxygen [6d].

\section{Results and Discussion}

2.1. Microflow Experiments. A commercially available falling film microreactor (FFMR-Standard by IMM, Mainz) was used for the present study [10]. This reactor has been successfully used for the photooxygenation of cyclopentadiene $[4 \mathrm{f}, \mathrm{g}]$. The experimental setup and a close-up of the reactor are shown in Figure 1. The reactor itself contained a reagent gas chamber with the reaction plate and an integrated heat exchanger. The reaction plate had 16 parallel microchannels of $1200 \mu \mathrm{m}$ width, $400 \mu \mathrm{m}$ depth, and $78 \mathrm{~mm}$ length each. The reaction mixture formed individual falling films by gravity in the channels. Air was blown over the liquid films at a rate of $26.5 \mathrm{~mL} / \mathrm{min}$ using a common electrical air pump in combination with a flow meter.

* Authors for correspondence: michael.oelgemoeller@jcu.edu.au
The large interfacial area within the reactor ensured effective saturation of the liquid film with oxygen. The front window of the reactor (dimensions: $55 \times 28 \mathrm{~mm} ; H \times W$ ) was made of quartz glass $(\lambda \geq 200 \mathrm{~nm})$. A conventional $18 \mathrm{~W}$ compact fluorescent lamp was installed in front of the falling film reactor at a distance of $10 \mathrm{~cm}$ from the reactor window. Alternatively, an array of 60 white LEDs with a total optical power of $3 \mathrm{~W}$ was used [11]. The setup was enclosed in a light-tight box that was cooled using a small fan. The reaction temperature inside the box was monitored using a standard laboratory thermometer and did not exceed $25^{\circ} \mathrm{C}$. The reactor was cooled with chilled water.

The reaction mixture containing the diol $\mathbf{1}$, rose bengal, and (aqueous) isopropanol was drawn from an amber round-bottom flask by a programmable rotary pump, whereas a second pump removed the product mixture from the reactor. All polytetrafluoroethylene (PTFE) tubing was wrapped with black masking tape to avoid any photoreaction with ambient light. Two flow rates were chosen, $0.08 \mathrm{~mL} / \mathrm{min}$ and $0.16 \mathrm{~mL} / \mathrm{min}$. Residence times $(\tau)$, film volumes $\left(V_{\text {film }}\right)$, film thicknesses $(\delta)$, and interfacial areas $(\alpha)$ were subsequently calculated for both values using Eqs (1-4) $[10,12]$ and the results are compiled in Table 1:

$$
\tau=\frac{V_{\text {film }}}{\dot{V}}
$$

where $V_{\text {film }}=$ volume of the film and $\dot{V}=$ flow rate of the liquid.

$$
V_{\text {film }}=\delta \times l \times B
$$

where $\delta=$ film thickness, $l=$ length of the channel, and $B=$ film width.

$$
\delta=\left[\frac{3 \times \dot{V} \times \eta}{\rho \times B \times g}\right]^{\frac{1}{3}}
$$

where $\dot{V}=$ flow rate of the liquid, $\eta=$ viscosity of the liquid, $\rho=$ density of the liquid, $B=$ width of film, and $g=$ acceleration due to gravity.

Scheme 1. Photooxygenation of 1,5-dihydroxynaphthalene (1)

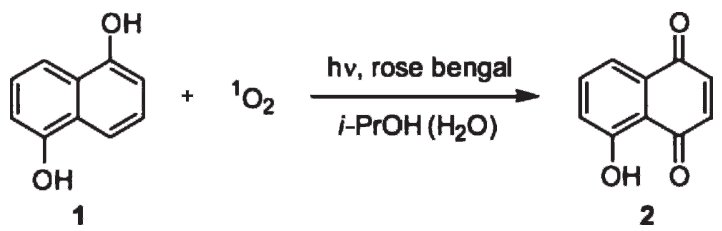


(a)

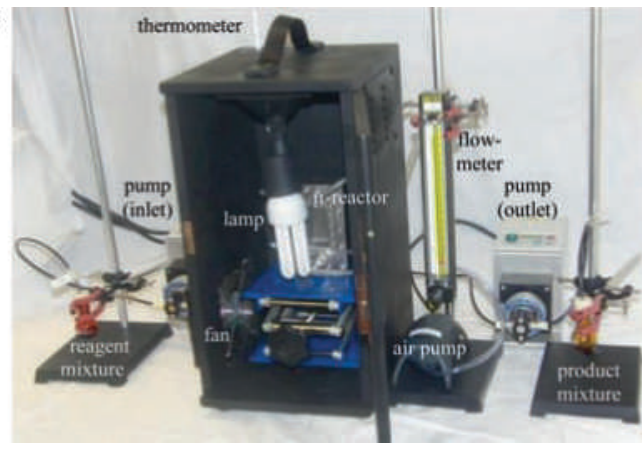

(b)

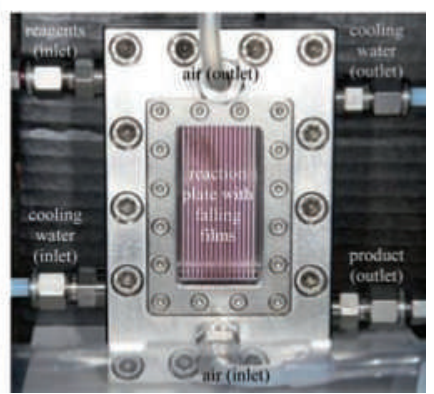

Figure 1. (a) Experimental setup in flow-through mode and (b) close-up of reactor with parallel falling films (the red color of the sensitizer can be clearly seen in each channel)

Table 1. Calculated residence times, film thicknesses, and film volumes Entry Flow rate Residence Film volume Film thickness Interfacial

\begin{tabular}{cccccc} 
& $(\mathrm{mL} / \mathrm{min})$ & time $(\mathrm{s})$ & $(\mathrm{mL})^{b}$ & $(\mu \mathrm{m})^{a, b}$ & area $\left(\mathrm{m}^{2} / \mathrm{m}^{3}\right)$ \\
\hline 1 & 0.08 & 32 & 0.043 & 41 & 24,438 \\
2 & 0.16 & 20 & 0.054 & 52 & 19,396
\end{tabular}

${ }^{a}$ Calculated using the viscosity and density of pure isopropanol at $20{ }^{\circ} \mathrm{C}$.

${ }^{b}$ Reaction plate with 16 microchannels of $1200 \mu \mathrm{m}$ width, $400 \mu \mathrm{m}$ depth, and $78 \mathrm{~mm}$ length each.

$$
\alpha=\frac{A}{V_{\text {film }}}
$$

where $A=$ surface area of the film and $V_{\text {film }}=$ volume of the film.

Owing to the lowest possible residence time of just 32 s/cycle, the reaction mixture was pumped in a closed loop in order to reach reasonable conversion rates. This was achieved by connecting the pumps via PTFE tubing once the reaction mixture was drawn completely into the reactor. Five cycles were initially chosen to keep operation time reasonable with $80 \mathrm{~min}$. The product mixture was released into an amber flask and evaporated to dryness. The conversion rates were subsequently determined by ${ }^{1} \mathrm{H}-\mathrm{NMR}$ spectroscopy (Table 2). Owing to the small amounts of material (total volume of $6 \mathrm{~mL}$ ), isolation of $\mathbf{2}$ was not attempted.

Initially, pure isopropanol was used as an environmentally benign solvent [13], and irradiations were conducted using an energy-saving fluorescent lamp [14]. After five cycles and a total residence time of $160 \mathrm{~s}$, a conversion of $10 \%$ of diol 1 was achieved (entry 1). Doubling the concentration of rose bengal gave a somewhat higher amount of $\mathbf{2}$ of $21 \%$ (entry 2), but the sensitizer remained partially undissolved and threatened to clog the narrow microstructures. When the concentrations of both starting materials were halved, $\mathbf{1}$ was converted to juglone (2) in an amount of $18 \%$ (entry 3 ). In all three cases, the reaction mixture showed a low transparency due to the poor solubility of rose bengal in neat isopropanol. When $10 \mathrm{vol} \%$ of water was applied as co-solvent, a fully transparent solution was obtained instead.
The highest conversion to $\mathbf{2}$ of $31 \%$ was subsequently achieved in aqueous isopropanol after $160 \mathrm{~s}$ (entry 4). Owing to its lower power output, the LED array gave significantly lower conversion rates of $9 \%$ and $8 \%$ (entries 5 and 6 ), respectively. The small drop in conversion for the reaction conducted at a higher flow rate (entry 6) might be explained by the reduction in interfacial area (Table 1), which overcompensated the slightly longer irradiation time. All reactions proceeded with high selectivity and no other products could be detected by NMR analysis. Preparative batch reactions performed for comparison supported this assumption, and isolated yields were similar to conversion rates (see below). Stability tests performed with pure $\mathbf{2}$ under irradiation conditions also gave high recoveries of $>80 \%$. A thin brownish coating was, however, formed on the reaction plate. The film most reasonably resulted from impurities present in diol $\mathbf{1}$ or from partial decomposition of the sensitizer rose bengal [15].

2.2. Batch Experiments. Analogue batch reactions were subsequently conducted on preparative $50 \mathrm{~mL}$ scales in Pyrex Schlenk flasks (inner- $\varnothing: 32 \mathrm{~mm}$ ) equipped with a cold finger (outer- $\varnothing: 24 \mathrm{~mm}$ ). The interfacial area of the flask was calculated to be $16.1 \mathrm{~m}^{2} / \mathrm{m}^{3}$. The tubes were inserted into a Rayonet chamber reactor, which was operated with $16 \times 8 \mathrm{~W}$ visible lamps. Air was purged into the solution via PTFE tubing with a suitable nozzle head at a rate of $26.5 \mathrm{~mL} / \mathrm{min}$. Samples were taken after $160 \mathrm{~s}$ and $5 \mathrm{~min}$ of light exposure, evaporated, and analyzed by ${ }^{1} \mathrm{H}-\mathrm{NMR}$ spectroscopy. After a total reaction time of $10 \mathrm{~min}$, the experiments were stopped, conversion values were determined, and juglone (2) was isolated by column chromatography (Table 3).

Irradiation in neat isopropanol furnished low conversions of $6 \%$ after $160 \mathrm{~s}, 8 \%$ after $5 \mathrm{~min}$, and $13 \%$ after 10 min (entry $1)$, respectively. At the end of the experimental run, the isolated yield of product 2 was established to be $12 \%$, suggesting that photodecomposition did not take place. Similar conversion rates of diol 1 of $6 \%, 8 \%$, and $14 \%$ were obtained when aqueous isopropanol was utilized as the solvent system (entry 2). The final isolated yield of juglone (2) was slightly lower with $10 \%$.

Table 2. Experimental data for the photooxygenation of 1 in the FFMR

\begin{tabular}{|c|c|c|c|c|c|c|}
\hline Entry & Solvent & Light source & $1(\mathrm{mmol} / \mathrm{L})$ & Rose bengal (mmol/L) & Residence time (s) & Conversion of $\mathbf{1}(\%)$ \\
\hline 1 & $i$-PrOH & Fluorescent bulb $(18 \mathrm{~W})$ & 10 & 0.49 & $32 \times 5^{b}\left(160^{c}\right)$ & 10 \\
\hline 2 & $i$-PrOH & Fluorescent bulb (18 W) & 10 & 0.98 & $32 \times 5^{b}\left(160^{c}\right)$ & 21 \\
\hline 3 & $i$-PrOH & Fluorescent bulb (18 W) & 5 & 0.25 & $32 \times 5^{b}\left(160^{c}\right)$ & 18 \\
\hline 5 & $i-\mathrm{PrOH} / \mathrm{H}_{2} \mathrm{O}(9: 1)$ & LED array $(3 \mathrm{~W})$ & 10 & 0.49 & $32 \times 5^{b}\left(160^{c}\right)$ & 9 \\
\hline 6 & $i-\mathrm{PrOH} / \mathrm{H}_{2} \mathrm{O}(9: 1)$ & LED array $(3 \mathrm{~W})$ & 10 & 0.49 & $20 \times 10^{b}\left(200^{c}\right)$ & 8 \\
\hline \multicolumn{7}{|c|}{$\begin{array}{l}{ }^{a} \text { Determined by }{ }^{1} \mathrm{H}-\mathrm{NMR} \text { spectroscopic analysis of the crude product }( \pm 2 \%) \text {. } \\
{ }^{b} \text { Number of cycles. } \\
{ }^{c} \text { Total residence time. }\end{array}$} \\
\hline
\end{tabular}


Table 3. Experimental data for the photooxygenation of $\mathbf{1}$ using Schlenk flasks

\begin{tabular}{|c|c|c|c|c|}
\hline \multirow[t]{2}{*}{ Entry } & \multirow[t]{2}{*}{ Solvent } & \multicolumn{2}{|c|}{ Conversion of $1(\%)^{a}$} & \multirow[t]{2}{*}{ Yields of $\mathbf{2}(\%)^{b}$} \\
\hline & & \multicolumn{2}{|c|}{$160 \mathrm{~s} 5 \mathrm{~min}(\%)^{a} 10 \mathrm{~min}(\%)^{a}$} & \\
\hline 1 & $i$-PrOH & 6 & 13 & 12 \\
\hline 2 & $i-\mathrm{PrOH} / \mathrm{H}_{2} \mathrm{O}(9: 1)$ & 6 & 14 & 10 \\
\hline
\end{tabular}

2.3. Reactor Comparison. The absorption spectrum of rose bengal in isopropanol was recorded and compared with the emission spectra of the three light sources applied (Figure 2a). The main emission band of both fluorescent lamps (bulb and tube) at $546 \mathrm{~nm}$ matched well with the main absorption of the sensitizer $\left(\lambda_{\max }=548 \mathrm{~nm}\right)$. Although the white LED panel showed a broader coverage, its main emissions did not correspond well with the maximum absorption of rose bengal. The penetration profile of light was subsequently calculated at $548 \mathrm{~nm}$ and compared to the path lengths of the falling films and the Schlenk tube (Figure 2b). Owing to the cold finger and the circular arrangement of the lamps in the Rayonet chamber reactor, the effective path length of the Schlenk flask was reduced to $4 \mathrm{~mm}$. At the given standard concentration of rose bengal $(0.49 \mathrm{mM})$, the falling film reactor allowed for optimal transmission of light through the microfilm. This feature, in combination with the high interfacial areas of $\sim 20,000 \mathrm{~m}^{2} / \mathrm{m}^{3}$, explains the superior performance of the microsystem over the batch system. Within the Schlenk flask, complete absorption of light was achieved below $1 \mathrm{~mm}$, which corresponded to $1 / 4$ of the effective path length. The turbulent bubble flow within the flask may have somewhat compensated for this disadvantage.

On the basis of the conversion rates alone, the falling film reactor equipped with the compact fluorescent lamp gave the best overall results. However, when the energy efficiencies (by Ryu et al. [16]) and energy efficiencies based on irradiated area (by Oelgemöller et al. [3a]) of the different setups were calculated for transformations under identical conditions (Table 4), the LED array gave significantly larger values of $69.2 \% \mathrm{~W}^{-1} \mathrm{~h}^{-1}$ and $6.55 \% \mathrm{~W}^{-1} \mathrm{~h}^{-1} \mathrm{~cm}^{-2}$ (entry 2). This somewhat unexpected finding may result from the superior coverage of the LED emission across the whole absorption spectrum of the sensitizer (Figure 2a). Despite its lower energy efficiencies of $38.8 \% \mathrm{~W}^{-1} \mathrm{~h}^{-1}$ and $3.67 \% \mathrm{~W}^{-1} \mathrm{~h}^{-1} \mathrm{~cm}^{-2}$ (entry 1 ), the compact fluorescent lamp furnished juglone (2) in a more convenient overall time frame of $80 \mathrm{~min}$. After an extended time period of $10 \mathrm{~min}$, the Rayonet reactor gave the lowest energy efficiency of just $1.1 \% \mathrm{~W}^{-1} \mathrm{~h}^{-1}$ or $0.013 \% \mathrm{~W}^{-1} \mathrm{~h}^{-1} \mathrm{~cm}^{-2}$ (entry 3 ), which is caused by the large nonirradiated area within its chamber and its small interfacial area.

\section{Conclusion}

In conclusion, we have demonstrated that juglone (2) can be obtained from the cheap and commercially available 1,5dihydroxynaphthalene (1) in a falling film microreactor. The conversion rates of up to $31 \%$ after just $160 \mathrm{~s}$ of irradiation far exceeded those achieved under conventional batch conditions. The naturally small reaction scale reduced the amounts of materials and consequently produced less waste [17]. The transformation furthermore made use of energy saving light sources, aqueous isopropanol as solvent, and air as oxidant, thus contributing to the growing field of "green photochemistry" [18].

\section{Experimental}

4.1. General. All starting materials and solvents were purchased from Sigma-Aldrich and were used without further purification unless otherwise noted. NMR spectra were recorded on a Bruker 400 Ultrashield ${ }^{\mathrm{TM}}\left({ }^{1} \mathrm{H} 400 \mathrm{MHz}\right.$ and $\left.{ }^{13} \mathrm{C} 100 \mathrm{MHz}\right)$ or a Varian Mercury $300\left({ }^{1} \mathrm{H} 300 \mathrm{MHz}\right)$ using the residual solvent signal as internal standard. Preparative chromatography was carried out using Merck silica gel 60 and pure chloroform (distilled prior to usage) as eluent.

\subsection{Irradiations}

4.2.1. Typical Irradiation Procedure for FFMR. 1,5Dihydroxynaphthalene (10 mg; $60 \mu \mathrm{mol})$ and rose bengal (3 mg; $3 \mu \mathrm{mol})$ were dissolved in isopropanol $(6 \mathrm{~mL})$ or an isopropanol/
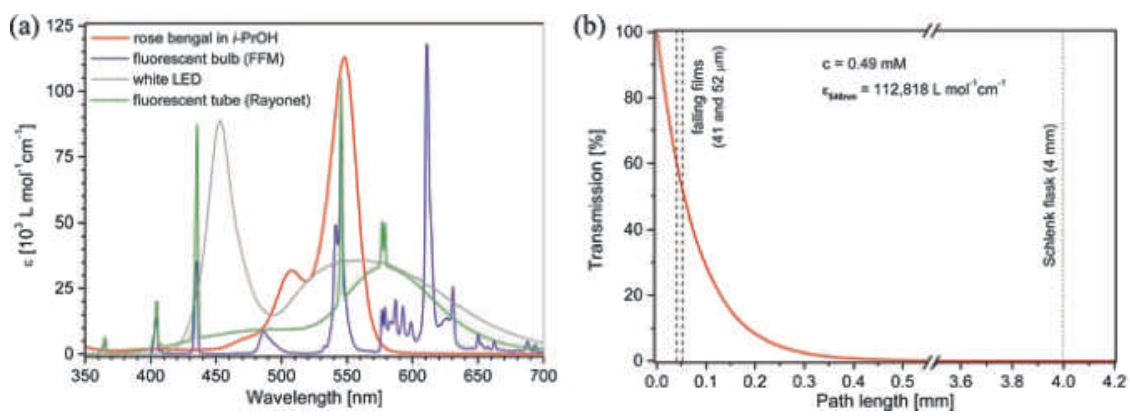

Figure 2. (a) UV-Vis spectra of rose bengal matched with the emission spectra of the light sources used (18-W compact fluorescent bulb; 3-W white LED panel; single 8-W fluorescent tube) and (b) light penetration profile. The vertical lines represent the path lengths of the falling films (broken) and the Schlenk flask (dotted)

Table 4. Selected energy efficiencies of the irradiation setups (aqueous $i-\mathrm{PrOH}$; rose bengal: $0.49 \mathrm{mM}$ )

\begin{tabular}{|c|c|c|c|c|c|c|c|}
\hline Entry & Reactor & Power (W) & Conversion $(\%)^{a}$ & Residence time & $\mathrm{Wh}^{b}$ & $\begin{array}{l}\text { Energy efficiency } \\
\left(\% \mathrm{~W}^{-1} \mathrm{~h}^{-1}\right)\end{array}$ & $\begin{array}{l}\text { Energy efficiency on irradiated area } \\
\left(\% \mathrm{~W}^{-1} \mathrm{~h}^{-1} \mathrm{~cm}^{-2}\right)^{c}\end{array}$ \\
\hline 1 & Falling film & 18 (bulb) & 31 & $160 \mathrm{~s}$ & 0.8 & 38.8 & 3.67 \\
\hline 2 & Falling film & 3 (LEDs) & 9 & $160 \mathrm{~s}$ & 0.13 & 69.2 & 6.55 \\
\hline 3 & Batch & 128 (Rayonet) & 14 & $10 \mathrm{~min}$ & 12.8 & 1.1 & 0.013 \\
\hline
\end{tabular}


water mixture $(9: 1 ; 6 \mathrm{~mL})$ and sonicated for $30 \mathrm{~min}$. The prepared reaction mixture was irradiated in a falling film microreactor (FFMR-Standard by IMM, Mainz) using a fluorescent lamp (Philips GENIE Warm White; $18 \mathrm{~W}$ ) or a white LED array (Powerfix ${ }^{\circledR}, 60$ LEDs, $3 \mathrm{~W}$ total). Two identical programmable rotary pumps (ISMATEC Reglo-CPF Digital) were used for influent and effluent transportation. During operation, the reactor was cooled with chilled water. Air was continuously blown over the falling films $(26.5 \mathrm{~mL} / \mathrm{min})$. The product mixture was collected in an amber round-bottom flask after five or ten cycles, respectively. Following evaporation of the solvent, the conversion rate was determined by $1 \mathrm{H}-\mathrm{NMR}$ spectroscopy of the crude product. The integration area for the quinonoid protons of juglone 2 (two doublets with an integration of 2) was compared to the integration area of two aromatic protons of 1,5-dihydroxynaphthalene $\mathbf{1}$ (most upfield doublet with an integration of 2).

4.2.2. Typical Irradiation Procedure for Batch Reactions 1,5-Dihydroxynaphthalene ( $80 \mathrm{mg} ; 0.5 \mu \mathrm{mol}$ ) and rose bengal $(25 \mathrm{mg} ; 25 \mu \mathrm{mol})$ were dissolved in isopropanol $(50 \mathrm{~mL})$ or an isopropanol/water mixture $(9: 1 ; 50 \mathrm{~mL})$ in a Pyrex Schlenk flask and sonicated for $30 \mathrm{~min}$. A cold finger was inserted into the flask and the setup was placed in a Rayonet RPR-200 chamber reactor (Southern New England) equipped with 16 visible lamps (Philips TL $8 \mathrm{~W} / 33-640 ; 8 \mathrm{~W}$ ). Two milliliters of samples were taken after $160 \mathrm{~s}$ and $5 \mathrm{~min}$, evaporated, and analyzed by 1H-NMR to determine conversions. After completed irradiation of $10 \mathrm{~min}$, the remaining solution was evaporated to dryness, the final conversion rate was determined by $1 \mathrm{H}-\mathrm{NMR}$ spectroscopy, and the crude product was purified by column chromatography ( $\mathrm{SiO} 2$, chloroform).

5-Hydroxy-1,4-naphthoquinone (2). Orange needles; $\mathrm{mp}$ $152^{\circ} \mathrm{C}$ (Lit.: $151-154^{\circ} \mathrm{C}$ [9f]). ${ }^{1} \mathrm{H}-\mathrm{NMR}$ (400 MHz, acetone- $d_{6}$ ) $\delta 7.04\left(\mathrm{~d}, 1 \mathrm{H},{ }^{3} \mathrm{~J}=10.4 \mathrm{~Hz}, \mathrm{H}_{\text {quin }}\right), 7.08\left(\mathrm{~d}, 1 \mathrm{H},{ }^{3} \mathrm{~J}=10.4 \mathrm{~Hz}\right.$, $\left.\mathrm{H}_{\text {quin }}\right), 7.33\left(\mathrm{dd}, 1 \mathrm{H},{ }^{3} \mathrm{~J}=8.4,{ }^{4} \mathrm{~J}=1.2 \mathrm{~Hz}, \mathrm{H}_{\text {arom }}\right), 7.58(\mathrm{dd}, 1 \mathrm{H}$, $\left.{ }^{3} J=7.6,{ }^{4} J=1.2 \mathrm{~Hz}, \mathrm{H}_{\text {arom }}\right), 7.78\left(\mathrm{dd}, 1 \mathrm{H},{ }^{3} J=8.4,7.6 \mathrm{~Hz}\right.$, $\left.\mathrm{H}_{\text {arom }}\right), 11.92(\mathrm{~s}, 1 \mathrm{H}, \mathrm{OH}) \mathrm{ppm} ;{ }^{13} \mathrm{C}-\mathrm{NMR}\left(100 \mathrm{MHz}\right.$, acetone- $\left.d_{6}\right)$ $\delta 114.0,118.1,123.5,130.8,135.5,137.6,138.6,160.6,183.2$, 189.3 ppm; calcd for $\mathrm{C}_{10} \mathrm{H}_{6} \mathrm{O}_{3}$ (\%): C 68.97, $\mathrm{H} 3.47$, found: C 68.25 , H 3.70

Acknowledgments. This work was financially supported by James Cook University (Competitive Research Incentive Grant, CRIG 2011, and Faculty Administered Internal Grant, FAIG 2011), the Irish Environmental Protection Agency (EPA, 2008-ET-MS-2-S2), and the Department of Environment, Heritage and Local Government (DEHLG, 2008-S-ET-2). C.L. thanks the Deutsche Forschungsgemeinschaft (DFG) for a research fellowship (GZ: LI2112/1-1). The authors thank Dr Alexander Yavorskyy for technical assistance.

\section{References and Notes}

1. For recent reviews, see (a) Oelgemöller, M.; Shvydkiv, O. Molecules 2011, 7, 1313-1322; (b) Coyle, E. E.; Oelgemöller, M. Photochem. Photobiol Sci. 2008, 7, 1313-1322; (c) Matsushita, Y.; Ichimura, T.; Ohba, N.; Kumada S.; Sakeda, K.; Suzuki, T.; Tanibata, H.; Murata, T. Pure Appl. Chem. 2007, 79, $1959-1968$

2. Braun, A. M.; Maurette, M.; Oliveros, E. Photochemical Technology, Wiley: Chichester, UK, 1991

3. For selected examples form our and other laboratories, see (a) Shvydkiv, O.; Yavorskyy, A.; Tan, S. B.; Nolan, K.; Hoffmann, N.; Youssef, A.; Oelgemöller, M. Photochem. Photobiol. Sci. 2011, 10, 1399-1404; (b) Shvydkiv, O.; Nolan, K.; Oelgemöller, M. Beilstein J. Org. Chem. 2011, 7, 1055-1063; (c) Yavorskyy, A.; Shvydkiv, O.; Nolan, K.; Hoffmann, N.; Oelgemöller, M. Tetrahedron Lett. 2011, 52, 278-280; (d) Shvydkiv, O; Yavorskyy, A.; Nolan, K.; Youssef, A. Riguet, E.; Hoffmann, N.; Oelgemöller, M. Photochem. Photobiol. Sci. 2010 9, 1601-1603; (e) Shvydkiv, O.; Gallagher, S.; Nolan, K.; Oelgemöller, M. Org. Lett. 2010, 12, 5170-5173; (f) Fukuyama, T.; Hino, Y.; Kamata, N.; Ryu I. Chem. Lett. 2004, 33, 1430-1431; (g) Tsutsumi, K.; Terao, K.; Yamaguchi,
H.; Yoshimura, S.; Morimoto, T.; Kakiuchi, K.; Fukuyama, T.; Ryu, I. Chem. Lett. 2010, 39, 828-829; (h) Vasudevan, A.; Villamil, C.; Trumbull, J.; Olson, J.; Sutherland, D.; Pan, J.; Djuric, S. Tetrahedron Lett. 2010, 51, 4007-4009 (i) Fuse, S.; Tanabe, N.; Yoshida, M.; Yoshida, H.; Doi, T.; Takahashi, T. Chem Commun. 2010, 46, 8722-8724.

4. (a) Lévesque, F; Seeberger, P. H. Org. Lett. 2011, 13, 5008-5011; (b) Park, C. P.; Maurya, R. A.; Lee, J. H.; Kim, D.-P. Lab Chip 2011, 11, 1941 1945; (c) Maurya, R. A.; Park, C. P.; Kim, D.-P. Beilstein J. Org. Chem. 2011 7, 1158-1163; (d) Carofiglio, T.; Donnola, P.; Maggini, M.; Rossetto, M.; Rossi, E. Adv. Synth. Catal. 2008, 350, 2815-2822; (e) Meyer, S.; Tietze, D.; Rau, S.; Schäfer, B. Kreisel, G. J. Photochem. Photobiol. A · Chem 2007, 186, 248 253; (f) Jähnisch, K.; Dingerdissen, U. Chem. Eng. Technol. 2005, 28, 426-427; (g) Jähnisch, K.; Dingerdissen, U. Chem. Ing. Tech. 2004, 76, 630-632. (h) Wootton, R. C. R.; Fortt, R.; de Mello, A. J. Org. Process Res. Dev. 2002, 6, 187-189.

5. (a) Clennan, E. L.; Pace, A. Tetrahedron 2005, 61, 6665-6691; (b) DeRosa, M. C.; Crutchley, R. J. Coord. Chem. Rev. 2002, 233-234, 351-371; (c) Iesce, M. R.; Cermola, F.; Temussi, F. Curr. Org. Chem. 2005, 9, 109-139; (d) Clennan, E. L. Tetrahedron 2000, 56, 9151-9179; (e) Gollnick, K. Chim. Ind 1982, 64, 156-166; (f) Rojahn, W.; Warnecke, H.-U. Dragoco-Report 1980, 27, $159-164$

6. (a) Haggiage, E.; Coyle, E. E.; Joyce, K.; Oelgemöller, M. Green Chem 2009, 11, 318-321; (b) Oelgemöller, M.; Healy, N.; de Oliveira, L.; Jung, C.; Mattay, J. Green Chem. 2006, 8, 831-834; (c) Oelgemöller, M.; Jung, C.; Mattay, J. Pure Appl. Chem. 2007, 79, 1939-1947; (d) Suchard, O.; Kane, R.; Roe, B. J.; Zimmerman, E.; Jung, C.; Waske, P. A.; Mattay, J.; Oelgemöller, M. Tetrahedron 2006, 62, 1467-1473; (e) Oelgemöller, M.; Jung, C.; Ortner, J.; Mattay, J.; Zimmermann, E. Green Chem. 2005, 7, 35-38; (f) Yavorskyy, A.; Shvydkiv, O. Limburg, C.; Nolan, K.; Delauré, Y.; Oelgemöller, M. Green Chem. 2012, 14 DOI:10.1039/C2GC16439F.

7. (a) Binder, R. G.; Benson, M. E.; Flath, R. A. Phytochemistry 1989, 28 2799-2801; (b) Moir, M.; Thomson, R. H. Phythochemistry 1973, 12, 13511353; (c) Ikekawa, T.; Lin Wang, E.; Hamada, M.; Takeuchi, T.; Umezawa, H Chem. Pharm. Bull. 1967, 15, 242-245; (d) Mylius, F. Ber. Dtsch. Chem. Ges., 1884, 17, 2411-2414.

8. (a) For $(S)$-espicufolin, see Tietze, L. F.; Gericke, K. M.; Reddy Singidi, R.; Schuberth, I. Org. Biomol. Chem. 2007, 5, 1191-1200; (b) for $( \pm)-\gamma$ indomycinone, see Hsu, D.-S.; Matsumoto, T.; Suzuki, K. Chem. Lett. 2006 35, 1016-1017; (c) For mensacarcin, see Tietze, L. F.; Günther, C.; Gericke, K. M.; Schuberth, I; Bunkoczi, G. Eur. J. Org. Chem 2005, 2459-2467; (d) for (+)-rubiginone B2, see Motoyoshiya, J.; Masue, Y.; Iwayama, G.; Yoshioka, S. Nishii, Y.; Aoyama, H. Synthesis 2004, 2099-2102; (e) for aloesaponarin I, see Bingham, S. J.; Tyman, J. H. P. J. Chem. Soc., Perkin Trans. 1 1997, 3637-3642; (f) for (+)-nocardione A, see Clive D. L. J.; Fletcher, S. P.; Liu, D. J. Org. Chem 2004, 69, 3282-3293; (g) for rac-frenolicin B, see Contant, P.; Haess, M.; Riegl, J.; Scalone, M.; Visnick, M. Synthesis 1999, 821-828; (h) for urdamycinone B, see Matsuo, G.; Miki, Y.; Nakata, M.; Matsumura, S.; Toshima, K. J. Org. Chem 1999, 64, 7101-7106; (i) for rac-juglomycin A, see Kraus, G. A.; Liu, P. Synth. Commun. 1996, 26, 4501-4506.

9. (a) Takizawa, S.-y.; Aboshi, R.; Murata, S. Photochem. Photobiol. Sci. 2011, 10, 895-903; (b) Oelgemöller, M.; Mattay, J.; Görner, H. J. Phys. Chem A 2011, 115, 280-285; (c) Murtinho, D.; Pinero, M.; Pereira, M. M.; Roch Gonsalves, A. M. d'A.; Arnaut, L. G.; da Graca Miguel, M.; Burrows, H. D. J. Chem. Soc. Perkin Trans. 2 2000, 2441-2447; (d) Croux, S. Maurette, M.-T. Hocquaux, M.; Ananides, A.; Braun, A. M.; Oliveros, E. New J. Chem. 1990, 14, 161-167; (e) Wurm, G.; Geres, U. Arch. Pharm. (Weinheim) 1985, 318, 931937; (f) Duchstein, H. J.; Wurm, G. Arch. Pharm. (Weinheim) 1984, 317, 809 812; (g) Griffiths, J.; Chu, K. Y.; Hawkins, C. J. Chem. Soc., Chem. Commun. 1976, 676-677.

10. (a) Steinfeldt, N.; Abdallah, R.; Dingerdissen, U.; Jähnisch, K. Org. Process Res. Dev. 2007, 11, 1025-1031; (b) Ehrich, H.; Linke, D. Morgenschweis, K.; Baerns, M.; Jähnisch, K. Chimia 2002, 56, 647-653.

11. (a) Carney, J. M.; Hammer, R. J.; Hulce, M.; Lomas, C. M.; Miyashiro, D. Tetrahedron Lett. 2011, 52, 352-355; (b) Kreisel, G.; Meyer, S.; Tietze, D.; Fidler, T.; Gorges, R.; Kirsch, A.; Schäfer, B.; Rau, S. Chem. Ing. Tech. 2007, 79 153-159; (c) Landgraf, S. Spectrochim. Acta A 2001, 57, 2029-2048.

12. van Dam, M. H. H.; Corriou, J.-P.; Midoux, N.; Lamine, A.; Roizard, S. C. Chem. Eng. Sci. 1999, 54, 5311-5318.

13. (a) Henderson, R. K.; Jiménez-González, C.; Constable, D. J. C.; Alston, S. R.; Inglis, G. G. A.; Fisher, G.; Sherwood, J.; Binks, S. P.; Curzons, A. D Green Chem. 2011, 13, 854-862; (b) Alfonsi, K.; Colberg, J.; Dunn, P. J.; Fevig, T.; Jennings, S.; Johnson, T. A.; Kleine, H. P.; Knight, C.; Nagy, M. A.; Perry D. A.; Stefaniak, M. Green Chem. 2008, 10, 31-36; (c) Capello, C.; Fischer, U.; Hungerbühler, K. Green Chem. 2007, 9, 927-934.

14. For a discussion of energy needs in chemical reactions, see Stankiewicz, A Chem. Eng. Res. Des. 2006, 84, 511-521.

15. (a) Zakrzewski, A. Neckers, D. C Tetrahedron 1987, 43, 4507-4512; (b) Neckers, D. C. J. Photochem. Photobiol. A: Chem. 1989, 47, 1-29.

16. (a) Fukuyama, T.; Kajihara, Y.; Hino, Y.; Ryu, I. J. Flow Chem. 2011 1, 40-45; (b) Sugimoto, A.; Fukuyama, T.; Sumino, Y.; Takagi, M.; Ryu, I. Tetrahedron 2009, 65, 1593-1598.

17. (a) Yoshida, J. I.; Kim, H.; Nagaki, A. ChemSusChem 2011, 4, 331-340; (b) Lerou, J. J.; Tonkovich, A. L.; Silva, L.; Perry, S.; McDaniel, J. Chem. Eng Sci. 2010, 65, 380-385; (c) Hessel, V.; Kralisch, D.; Krtschil, U. Energy Environ Sci. 2008, 1, 467-478; (d) Mason, B. P.; Price, K. E.; Steinbacher, J. L.; Bogdan, A. R.; McQuade, D. T. Chem. Rev. 2007, 107, 2300-2318.

18. (a) Ciana, C. L.; Bochet, C. G. Chimia 2007, 61, 650-654; (b) Schiel, C.; Oelgemöller, M.; Ortner, J.; Mattay J. Green Chem. 2001, 3, 224-228 (c) Schiel, C.; Oelgemöller, M.; Mattay, J. Synthesis 2001, 1275-1279; (d) Albini, A.; Fagnoni, M.; Mella, M. Pure Appl. Chem. 2000, 72, 1321-1326. 